\title{
Detection of hemoplasma and Bartonella species and co-infection with retroviruses in cats subjected to a spaying/neutering program in Jaboticabal, SP, Brazil
}

Detecção de hemoplasmas e Bartonella sp. e co-infecção com retrovírus em gatos submetidos a um programa de castração/esterilização em Jaboticabal, SP, Brasil

Caroline Plácidi de Bortolii ${ }^{1}$ Marcos Rogério André ${ }^{1}$; Meire Christina Seki ${ }^{1}$; Aramis Augusto Pinto ${ }^{1}$; Saulo de Tarso Zacarias Machado²; Rosangela Zacarias Machado ${ }^{1 *}$

\begin{abstract}
${ }^{1}$ Faculdade de Ciências Agrárias e Veterinárias - FCAV, Universidade Estadual Paulista - UNESP, Campus Jaboticabal, Jaboticabal, SP, Brasil

${ }^{2}$ Faculdade de Ciências Agrárias e Veterinárias - FCAV, Universidade Estadual Paulista — UNESP, Campus Araçatuba, Araçatuba, SP, Brasil
\end{abstract}

Received September 28, 2011

Accepted December 8, 2011

\begin{abstract}
Hemotrophic mycoplasmas and Bartonella species are important pathogens that circulate between cats and invertebrate hosts, occasionally causing diseases in humans. Nevertheless, there are few reports on occurrences of these agents in cats in Brazil. The present study aimed to detect the presence of hemoplasma and Bartonella DNA by means of PCR and sequencing. FIV antigens and anti-FeLV antibodies, were studied by using a commercial kit on blood and serum samples, respectively, among 46 cats that were sampled during a spaying/neutering campaign conducted in Jaboticabal, SP. Three (6.5\%) cats were positive for hemoplasmas: two (4.3\%) for 'Candidatus M. haemominutum' and one (2.2\%) for both M. haemofelis and 'Candidatus M. turicensis'. One of the two 'Candidatus M. haemominutum'infected cats was also positive for FeLV antigens and showed antibodies for FIV. Two cats (4.3\%) were positive for $B$. henselae. One of them was also positive for FeLV antigens. Eight cats (17.4\%) were positive for FeLV, and just one (2.2\%) showed anti-FIV antibodies. Bartonella species and hemoplasmas associated with infection due to retroviruses can circulate among apparently healthy cats.
\end{abstract}

Keywords: Hemotrophic mycoplasmas, Bartonella henselae, FIV, FeLV, cats.

\section{Resumo}

Micoplasmas hemotróficos e espécies de Bartonella são importantes patógenos que circulam entre gatos e hospedeiros invertebrados, causando ocasionalmente doenças no homem. Apesar disto, poucos são os estudos acerca da ocorrência destes agentes entre gatos no Brasil. O presente estudo objetivou detectar o DNA de hemoplasmas e Bartonella sp. pela PCR e sequenciamento. Antígeno de FIV e anticorpos anti-FeLV foram estudados utilizando um "kit" comercial, em amostras de sangue e soro, respectivamente, de 46 gatos amostrados em uma campanha de castraçáo em Jaboticabal, SP. Três gatos (6,5\%) foram positivos para hemoplasmas: dois (4,3\%) para 'Candidatus M. haemominutum' e um (2,2\%) para M. haemofelis and 'Candidatus M. turicensis'. Um dos gatos positivos para 'Candidatus M. haemominutum' mostrou-se também positivo na detecção de antígeno de FeLV e de anticorpos para FIV. Dois (4,3\%) gatos mostraramse positivos para $B$. henselae, sendo que um deles também se mostrou positivo para antígeno de FeLV. Oito gatos $(17,4 \%)$ foram positivos para FeLV, e apenas um gato mostrou anticorpos anti-FIV. Bartonella sp. e hemoplasmas associados à infecção por retrovírus podem circular entre gatos aparentemente saudáveis.

Palavras-chave: Micoplasmas hemotróficos, Bartonella henselae, FIV, FeLV, gatos.

\footnotetext{
*Corresponding author: Rosangela Zacarias Machado

Laboratório de Imunoparasitologia, Departamento de Patologia Veterinária,

Faculdade de Ciências Agrárias e Veterinárias,

Universidade Estadual Paulista Júlio de Mesquita Filho - UNESP,

Campus de Jaboticabal, Via de Acesso Prof. Paulo Donato Castellane, s/n,

Zona Rural, CEP 14884-900, Jaboticabal, SP, Brasil

e-mail: zacarias@fcav.unesp.br
} 


\section{Introduction}

Arthropod-borne bacterial agents have arisen as emerging pathogens over recent decades, due to ecological and climatic changes (SHAW et al., 2001). In this context, hemotrophic mycoplasmas and Bartonella species appear to be important pathogens that circulate between cats and invertebrate hosts, occasionally causing diseases in human beings. Mycoplasma haemofelis and Bartonella henselae have been detected in a human immunodeficiency virusinfected patient in Brazil (DOS SANTOS et al., 2008).

Feline hemotrophic mycoplasmas (hemoplasmas) comprise a group of bacteria that can induce hemolytic anemia in cats. Mycoplasma hemofelis is the most pathogenic species; 'Candidatus Mycoplasma haemominutum' and 'Candidatus Mycoplasma turicensis' are less pathogenic species (TASKER et al., 2010). Hemoplasma-infected cats show unspecific clinical signs like pallor, anorexia, lethargy, weight loss, depression, dehydration and pyrexia (MESSICK et al., 2003; TASKER et al., 2010).

The genus Bartonella comprises a group of fastidious Gramnegative bacteria that are very well adapted to mammalian hosts and develop long-lasting intraerythrocytic bacteremia (BREITSCHWERDT et al., 2010). Cats are the major reservoirs for B. henselae, B. clarridgeiae and B. koehlerae (BREITSCHWERDT; KORDICK, 2000; BREITSCHWERDT et al., 2010). Although cats rarely show clinical manifestations caused by Bartonella species, there have been reports of occurrences of fever, lethargy, anorexia, reproductive failure, lymphadenopathy, stomatitis, uveitis and neurological dysfunction (BREITSCHWERDT; KORDICK, 2000; BREITSCHWERDT et al., 2010; GUPTILL et al., 1998).

There are few reports on occurrences of hemoplasmas (BATISTA, 2004; BAUMANN et al., 2006; HORA, 2008; MACIEIRA et al., 2008; SANTOS et al., 2009) and Bartonella (STAGGEMEIER et al., 2010; SOUZA et al., 2010; CRISSIUMA et al., 2011), in infections among cats in Brazil. The present study aimed to detect the presence of hemoplasma and Bartonella species, FeLV antigens and FIV antibodies in blood samples from cats subjected to a spaying/ neutering program in Jaboticabal, SP, Brazil.

\section{Materials and Methods}

Between January and July 2009, EDTA blood and serum samples were collected from all 46 clinically healthy cats that were presented to a free spaying/neutering program that was conducted in the city of Jaboticabal, SP, Brazil. DNA was extracted from $200 \mu \mathrm{L}$ of whole blood sample using the QIAamp DNA Blood Mini kit (QIAGEN, Valencia, California, USA), in accordance with the manufacturer's instructions.

Partial sequences of the $16 S$ rRNA gene of $M$. haemofelis, 'Candidatus Mycoplasma haemominutum' and 'Candidatus Mycoplasma turicensis' were amplified by means of PCR, in reaction mixtures of final volume $25 \mu \mathrm{L}$, containing $5 \mu \mathrm{L}$ of template DNA, 10X PCR buffer, $1.0 \mathrm{mM}$ of $\mathrm{MgCl}_{2}, 0.2 \mathrm{mM}$ of deoxynucleotide triphosphate (dNTPs) mixture, 1.5 U of Taq DNA polymerase (Invitrogen, Carlsbad, California, USA) and $0.2 \mathrm{mM}$ of primers that had previously been described (BERENT et al., 1998; FOLEY et al., 1998; SANTOS et al., 2009). Regarding the high similarity found in 16S rRNA sequences between $M$. haemofelis and $M$. haemocanis, samples that were positive in the above-described PCRs were subjected to another PCR test based on the RNAase P gene ( $r n p b)$, using primers, reagent concentrations and reaction conditions that had previously been described (BIRKENHEUER et al., 2002).

Screening for the genus Bartonella was performed by means of PCR targeting the intergenic transcribed spacer (ITS), as described previously (MAGGI; BREITSCHWERDT, 2005a; DINIZ et al., 2007). For further molecular characterization and species differentiation, samples that were positive in ITS amplification were tested for other genes: the bacteriophage-associated heme-binding protein gene (pap31) (MAGGI; BREITSCHWERDT, 2005b); the RNA polymerase beta subunit gene $(r p o B)$ (DINIZ et al., 2007); the riboflavin synthase gene ( $r i b C$ ) (JOHNSON et al., 2003); and the citrate synthase gene ( $g l t A$ ) (NORMAN et al., 1995; WINOTO et al., 2005).

Fragments of the expected size from $M$. haemofelis, 'Candidatus M. haemominutum' and 'Candidatus M. turicensis', cloned into pGEM T-Easy Vector System II (Promega, Madison, Wisconsin, USA), were kindly supplied by Dr. Joanne B. Messick, Purdue University, West Lafayette, IN, USA, and were used as positive controls. Bartonella henselae DNA, obtained from a cat in São Luís, Maranhão, was used as the positive control in Bartonella PCR assays (GenBank Access Number HQ012581). Ultra-pure sterile water was used as the negative control. In order to prevent PCR contamination, the DNA extraction, reaction setup, PCR amplification and electrophoresis were performed in separate rooms.

The reaction products were purified using the Silica Bead DNA Gel Extraction Kit (Fermentas, São Paulo, SP, Brazil). Purified amplified DNA fragments from positive samples were subjected to sequence confirmation in an automatic sequencer (ABI Prism 310 Genetic Analyzer; Applied Biosystems/Perkin Elmer) and were used for subsequent phylogenetic analysis. Consensus sequences were obtained through analyzing sense and antisense sequences using the CAP3 program (http://mobyle.pasteur.fr/ cgi-bin/MobylePortal/portal.py). Comparisons with sequences deposited in GenBank were made using the basic local alignment search tool (BLAST).

A commercially available immunoassay was used to detecting FeLV antigens and antibodies for FIV in cat serum samples $(\mathrm{n}=46)$. This system, the Snap ${ }^{\mathrm{TM}}$ Combo FeLV antigen/FIV (feline immunodeficiency virus) antibody test kit (IDEXX Laboratories, Inc., Westbrook, Maine, USA), was used in accordance with the manufacturer's recommendations.

\section{Results}

Among the 46 sampled cats, three $(6.5 \%)$ were positive for hemoplasmas: two for 'Candidatus M. haemominutum' and one for both $M$. haemofelis and 'Candidatus M. turicensis', based on sequencing confirmation. One of the 'Candidatus M. haemominutum'-infected cats was positive for FeLV antigens and showed antibodies for FIV. The sequenced products showed $83 \%$ identicalness with 16S rRNA $M$. haemofelis (EU930823), 66\% identicalness with rnpb $M$. haemofelis (EU078617), 100\% 
identicalness with 'Candidatus M. turicensis' (EU839977), 99-100\% identicalness with 16S rRNA 'Candidatus M. haemominutum' (EU839983; AM745338) and 90-91\% identicalness with 'Candidatus M. haemominutum' (AY150990) (Table 1).

Two cats (4.3\%) were positive for B. henselae. One of them was also positive for FeLV antigens. The analysis on the sequenced products showed that they presented 98-99\% identicalness with $B$. henselae (access numbers FJ832096, DQ529247 and DQ529248) (Table 2).

Fleas were found parasitizing 10 out of the 46 animals at the time of blood collection. Eight cats were positive for FeLV antigens, and just one showed antibodies for FIV. No fleas were found in any of the hemoplasma-infected cats. One B. henselaepositive cat was parasitized by fleas and tested positive for FeLV antigens at the time of sample collection.

\section{Discussion}

The present study showed that hemoplasma and Bartonella species circulate among household cats in Jaboticabal, SP, as well as the feline retroviruses FeLV and FIV. The prevalences of M. haemofelis, 'Candidatus M. haemominutum' and 'Candidatus M. turicensis' among the sample were $2.1 \%, 4.3 \%$ and $2.1 \%$, respectively. The prevalences among domestic cats around the world are $0.4 \%$ to $35 \%$ for 'Candidatus $\mathrm{M}$. haemominutum', $0.3 \%$ to $6.5 \%$ for 'Candidatus M. turicensis', $0.125 \%$ to $10 \%$ to Mycoplasma haemofelis and 0 to $0.7 \%$ for 'Candidatus M. haematoparvum' (TASKER et al., 2010). In Brazil, the prevalences of hemoplasmas among healthy and anemic cats are, respectively, $2.2 \%$ and $38 \%$ for M. haemofelis, $4 \%$ and $13.5 \%$ for 'Candidatus M. haemominutum' and $0.37 \%$ and $2.7 \%$ for 'Candidatus $M$. turicensis' (BATISTA, 2004; BAUMANN et al., 2006; MACIEIRA et al., 2008; HORA, 2008; SANTOS et al., 2009).

In the present study, co-infection of $M$. haemofelis and 'Candidatus M. turicensis' was found in one cat. Previously, co-infection of $M$. haemofelis and 'Candidatus M. haemominutum' has been reported in cats in the states of São Paulo (BATISTA, 2004), Paraná (BAUMANN et al., 2006), and Rio de Janeiro (MACIEIRA et al., 2008).

Mycoplasma haemofelis is the most pathogenic hemoplasma and it has been incriminated in hemolytic crises, even in immunocompetent cats (WILLI et al., 2007). 'Candidatus M. haemominutum' infections may cause anemia when animals are co-infected with retroviruses, and 'Candidatus M. turicensis' may cause this when cats are co-infected with other hemoplasmas or are immunosuppressed (WILLI et al., 2007). Although the hemoplasma-positive cats in the present study fulfilled at least one of the three situations described above, all of them were apparently healthy at the time of sample collection.

One of the 'Candidatus M. haemominutum'-infected cats was positive for FeLV antigens and showed antibodies for FIV. Cats infected with FIV or co-infected with FIV and FeLV are likely to be at higher risk of harboring 'Candidatus M. haemominutum' than retrovirus-negative cats (LURIA et al., 2004; HORA, 2008; MACIEIRA et al., 2008).

In our study, Bartonella henselae DNA was detected in two out of the 46 sampled cats (4.3\%). In Brazil, few reports have been produced concerning the epidemiology of bartonellosis. Bartonella henselae and B. clarridgeiae DNA was detected in $10.6 \%$ and $6.3 \%$ of the blood samples, respectively, from 40 cats at an animal shelter in Nova Hamburgo, state of Rio Grande do Sul (STAGGEMEIER et al., 2010). Using molecular techniques, high prevalence $(97.3 \%)$ of Bartonella spp. was found among cats in Vassouras, state of Rio de Janeiro (SOUZA et al., 2010). Also, Bartonella spp. DNA was detected in 17 out of 40 clinically healthy cats that were treated in a spaying/neutering program in the city of Rio de Janeiro (CRISSIUMA et al., 2011).

Cats are the main reservoirs for $B$. henselae, $B$. clarridgeiae and B. koehlerae (BREITSCHWERDT et al., 2010). Bartonella henselae is incriminated as the causative agent of cat scratch disease, ocular manifestations, encephalopathy, osteomyelitis and hepatic peliosis in humans (LAMAS et al., 2008). In Rio

Table 1. Degree of similarity according to Blast, of hemoplasma isolates among cats in Jaboticabal, SP, Brazil.

\begin{tabular}{ccccc}
\hline Animal & \multicolumn{4}{c}{ \% similarity according to Blast } \\
\cline { 2 - 5 } & $\begin{array}{c}\text { 16S rRNA gene } \\
\text { (600 bp fragment) }\end{array}$ & $\begin{array}{c}\text { 16S rRNA gene } \\
\text { (1475 bp fragment) }\end{array}$ & $\begin{array}{c}\text { CMt 16S } \\
\text { rRNA gene }\end{array}$ & $\begin{array}{c}\text { Mycoplasma sp. } \\
\text { rnpB gene }\end{array}$ \\
\hline G321 & $M f 83 \%$ (EU930823) & Mf $83 \%$ (EU839978) & $C M t 100 \%$ (EU839977) & $M f 66 \%(E U 078617)$ \\
G7 & $C M h 99 \%$ (EU839983) & $C M h 100 \%(A M 745338)$ & Negative & $C M h 90 \%(A Y 150990)$ \\
G355 & $C M h 99 \%$ (EU839984) & $C M h 100 \%(A M 745338)$ & Negative & $C M h 91 \%(A Y 150990)$ \\
\hline
\end{tabular}

Mycoplasma haemofelis = Mf; 'Candidatus Mycoplasma haemominutum' = CMh; 'Candidatus Mycoplasma turicensis' = CMt.

Table 2. Degree of similarity according to Blast, Bartonella henselae isolates among cats in Jaboticabal, SP, Brazil.

\begin{tabular}{ccccccc}
\hline \multirow{2}{*}{ Animal } & City & \multicolumn{5}{c}{ \% similarity according to Blast } \\
\cline { 3 - 7 } & & ITS & PAP 31 gene & RPOB gene & gltA gene & ribC ene \\
\hline \multirow{2}{*}{ G302 } & Jaboticabal & $\begin{array}{c}99 \% B h \\
(\mathrm{FJ} 832096)\end{array}$ & negative & negative & $\begin{array}{c}99 \% \mathrm{Bh} \\
(\mathrm{HQ} 012580)\end{array}$ & negative \\
\hline \multirow{2}{*}{$\mathrm{G} 312$} & Jaboticabal & $\begin{array}{c}98 \% B h \\
(\mathrm{DQ} 529247)\end{array}$ & $\begin{array}{c}99 \% B h \\
(\mathrm{DQ} 529248)\end{array}$ & negative & $\begin{array}{c}99 \% \mathrm{Bh} \\
(\mathrm{HQ} 012580)\end{array}$ & negative \\
\hline
\end{tabular}


de Janeiro, HIV-infected individuals and breeding cats were found to be at higher risk of Bartonella infection (LAMAS et al., 2010). Although the prevalence of Bartonella sp. infection found among the cats in Jaboticabal was low, these animals may act as a source of infection of $B$. henselae for humans through scratches contaminated by flea feces or bites contaminated with infected blood of cats (CHOMEL et al., 1996).

In Japan, where cats have been tested for antibodies to both FIV and $B$. henselae, significantly higher incidence of lymphadenopathy and gingivitis was observed among cats with serological evidence of infection with both of these organisms (UENO et al., 1996). Since FIV is associated with decreased levels of CD41 lymphocytes, these results suggest that co-infection with $B$. henselae in an immunodeficient cat can induce specific disease manifestations (BREITSCHWERDT et al., 2010). In our study, although one cat was positive for both $B$. henselae and $\mathrm{FeLV}$, it was apparently asymptomatic. Cats may be more likely to show clinical signs when infected with a non-reservoir-adapted Bartonella species (BREITSCHWERDT et al., 2010). Bartonella sp. induces asymptomatic infections when parasitizing preferred hosts, through behaving as a stealth pathogen (KORDICK; BREITSCHWERDT, 1998). While some seroepidemiological studies have showed a lack of association between feline retroviral infection and seroreactivity to B. henselae (GLAUS et al., 1997; MARUYAMA et al., 1998; LURIA et al., 2004), a recent study found that the course of natural $B$. henselae infection in cats does not seem to be influenced by immunosuppressive viral infections, but that latent FeLV infection may predispose cats to $B$. henselae infection or persistence (BUCHMANN et al., 2010).

As in the present study, low seroprevalences of $2 \%$ and $1.5 \%$ for $B$. henselae and B. vinsonii berkhoffic, respectively, and low molecular prevalences of $1 \%$ and $0.5 \%$ for $B$. henselae and B. vinsonii berkhoffii were found among $198 \mathrm{dogs}$ in the state of São Paulo (DINIZ et al., 2007).

Among cats, the flea Ctenocephalides felis is the main vector of $B$. henselae (CHOMEL et al., 1996). At the time of sample collection in the present study, fleas were found in one of the two Bartonella-infected cats. On the other hand, fleas were not found parasitizing hemoplasma-positive cats. Although a previous attempt to show experimental transmission between cats via fleas was inconclusive (WOODS et al., 2005), C. felis fleas are also considered to be the main vectors for hemoplasmas among cats (SHAW et al., 2001).

\section{Conclusion}

In conclusion, we showed that cats in the Jaboticabal region are exposed to retroviruses, hemoplasmas and Bartonella species. Retroviruses associated with hemoplasma and Bartonella species can circulate even in apparently asymptomatic cats. Molecular and serological surveys are needed, in order to attempt to investigate the frequency of these infections among cats and other animal species in other regions of Brazil. In addition, further studies should be conducted with the aim of elucidating the role of cats in the epidemiology of vector-borne bacterial zoonotic diseases in Brazil.

\section{Acknowledgements}

The authors would like to thank the Research Support Foundation of the State of São Paulo (Fundação de Amparo à Pesquisa do Estado de São Paulo, FAPESP) for providing a scholarship (2009/53610-5) and financial support (08/55570-8).

\section{References}

Batista TN. Freqüência de infecção do Mycoplasma haemofelis e 'Candidatus Mycoplasma haemominutum' em gatos (Felis catus) [Dissertação]. Botucatu: Universidade Estadual Paulista Júlio de Mesquita Filho; 2004.

Baumann A, Guimarães AMS, Silva CC, Yamaguti M, Kozemjakim DA, Messick JB, et al. Mycoplasma haemofelis and 'Candidatus Mycoplasma haemominutum' detection by PCR in anemic domestic cats (Felis catus) from Curitiba, Brazil: A Preliminary Study. Vet Clin Path 2006; 35: 370.

Berent LM, Messick JB, Cooper SK. Detection of Haemobartonella felis in cats with experimentally induced acute and chronic infections, using a polymerase chain reaction assay. Am J Vet Res 1998; 59(10): 1215-1220. PMid:9781450.

Birkenheuer AJ, Breitschwerdt EB, Alleman AR, Pitulle C. Differentiation of Haemobartonella canis and Mycoplasma haemofelis on the basis of comparative analysis of gene sequences. Am JVet Res 2002; 63(10): 13851388. http://dx.doi.org/10.2460/ajvr.2002.63.1385

Breitschwerdt EB, Kordick DL. Bartonella infection in animals: carriership, reservoir potential, pathogenicity, and zoonotic potential for human infection. Clin Microbiol Rev 2000; 13(3): 428-438. http:// dx.doi.org/10.1128/CMR.13.3.428-438.2000

Breitschwerdt EB, Maggi RG, Chomel BB, Lappin MR. Bartonellosis: an emerging infectious disease of zoonotic importance to animals and human beings. J Vet Emerg Crit Care (San Antonio) 2010; 20(1): 8-30. http://dx.doi.org/10.1111/j.1476-4431.2009.00496.x

Buchmann AU, Kershaw O, Kempf VAJ, Gruber AD. Does a feline leukemia virus infection pave the way for Bartonella henselae infection in cats? J Clin Microbiol 2010; 48(9): 3295-300. http://dx.doi.org/10.1128/ JCM.00750-10

Chomel BB, Kasten RW, Floyd-Hawkins K, Chi B, Yamamoto K, Roberts-Wilson J, et al. Experimental transmission of Bartonella henselae by the cat flea. J Clin Microbiol 1996; 34(8): 1952-1956.

Crissiuma A, Favacho A, Gershony L, Mendes-de-Almeida F, Gomes R, Mares-Guia A, et al. Prevalence of Bartonella species DNA and antibodies in cats (Felis catus) submitted to a spay/neuter program in Rio de Janeiro, Brazil. J Feline Med Surg 2011; 13(2): 149-151. http:// dx.doi.org/10.1016/j.jfms.2010.08.010

Diniz PP, Maggi RG, Schwartz DS, Cadenas MB, Bradley JM, Hegarty $\mathrm{B}$, et al. Canine bartonellosis: serological and molecular prevalence in Brazil and evidence of co-infection with Bartonella henselae and Bartonella vinsonii subsp. berkhoffii. Vet Res 2007; 38(5): 697-710. http://dx.doi. org/10.1051/vetres:2007023

Dos Santos AP, Dos Santos RP, Biondo AW, Dora JM, Goldani LZ, De Oliveira ST, et al. Hemoplasma infection in HIV-positive patient, Brazil. Emerg Infect Dis 2008; 14(12): 1922-1924. http://dx.doi.org/10.3201/ eid1412.080964 
Foley JE, Harrus S, Poland A, Chomel B, Pedersen NC. Molecular, clinical, and pathologic comparison of two distinct strains of Haemobartonella felis in domestic cats. Am J Vet Res 1998; 59(12): 1581-1588.

Glaus T, Hofmann-Lehmann R, Greene C, Glaus B, Wolfensberger C, Lutz H. Seroprevalence of Bartonella henselae infection and correlation with disease status in cats in Switzerland. J Clin Microbiol 1997; 35(11): 2883-2885.

Guptill L, Slater LN, Wu CC, Lin TL, Glickman LT, Welch DF, et al. Evidence of reproductive failure and lack of perinatal transmission of Bartonella henselae in experimentally infected cats. Vet Immunol Immunopathol 1998; 65(2-4): 177-189. http://dx.doi.org/10.1016/ S0165-2427(98)00153-6

Hora AS. Micoplasmas hemotrópicos como potenciais agentes causadores de anemia em felinos domésticos [Dissertação]. São Paulo: Universidade de São Paulo; 2008.

Johnson G, Ayers M, McClure SC, Richardson SE, Tellier R. Detection and identification of Bartonella species pathogenic for humans by PCR amplification targeting the riboflavin synthase gene (ribC). J Clin Microbiol 2003; 41(3): 1069-1072. http://dx.doi.org/10.1128/ JCM.41.3.1069-1072.2003

Kordick DL, Breitschwerdt EB. Persistent infection of pets within a household with three Bartonella species. Emerg Infect Dis 1998; 4(2): 325-328. http://dx.doi.org/10.3201/eid0402.980225

Lamas C, Curi A, Bóia M, Lemos E. Human bartonellosis: seroepidemiological and clinical features with an emphasis on data from Brazil - a review. Mem Inst Oswaldo Cruz 2008; 103(3): 221-235. http://dx.doi.org/10.1590/S0074-02762008000300001

Lamas CC, Mares-Guia MA, Rozental T, Moreira N, Favacho AR, Barreira J, et al. Bartonella spp. infection in HIV positive individuals, their pets and ectoparasites in Rio de Janeiro, Brazil: serological and molecular study. Acta Trop 2010; 115(1-2): 137-141. http://dx.doi.org/10.1016/j. actatropica.2010.02.015

Luria BJ, Levy JK, Lappin MR, Breitschwerdt EB, Legendre AM, Hernandez JA, et al. Prevalence of infectious diseases in feral cats in Northern Florida. J Feline Med Surg 2004; 6(5): 287-296. http://dx.doi. org/10.1016/j.jfms.2003.11.005

Macieira DB, De Menezes Rde C, Damico CB, Almosny NR, McLane HL, Daggy JK, et al. Prevalence and risk factors for hemoplasmas in domestic cats naturally infected with feline immunodeficiency virus and/or feline leukemia virus in Rio de Janeiro -- Brazil. J Feline Med Surg 2008; 10(2): 120-129. http://dx.doi.org/10.1016/j. jfms.2007.08.002

Maggi RG, Breitschwerdt EB. Potential limitations of the 16S-23S rRNA intergenic region for molecular detection of Bartonella species. J Clin Microbiol 2005a; 43(3): 1171-1176. http://dx.doi.org/10.1128/ JCM.43.3.1171-1176.2005

Maggi RG, Breitschwerdt EB. Isolation of bacteriophages from Bartonella vinsonii subsp. berkhoffii and the characterization of Pap-
31 gene sequences from bacterial and phage DNA. J Mol Microbiol Biotechnol 2005b; 9(1): 44-51. http://dx.doi.org/10.1159/000088145

Maruyama S, Hiraga S, Yokoyama E, Naoi M, Tsuruoka Y, Ogura Y, et al. Seroprevalence of Bartonella henselae and Toxoplasma gondii infections among pet cats in Kanagawa and Saitama Prefectures. $J$ Vet Med Sci 1998; 60(9): 997-1000. http://dx.doi.org/10.1292/jvms.60.997

Messick JB. New perspectives about hemotrophic mycoplasma (formerly, Haemobartonella and Eperythrozoon species) infections in dogs and cats. Vet Clin North Am Small Anim Pract 2003; 33(6): 1453-1465. http:// dx.doi.org/10.1016/j.cvsm.2003.08.002

Norman AF, Regnery R, Jameson P, Greene C, Krause DC. Differentiation of Bartonella-like isolates at the species level by PCRrestriction fragment length polymorphism in the citrate synthase gene. J Clin Microbiol 1995; 33(7): 1797-1803.

Santos AP, Messick JB, Biondo AW, Oliveira ST, Pedralli V, Lasta CS, et al. Design, optimization, and application of a conventional PCR assay with an internal control for detection of 'Candidatus Mycoplasma turicensis' 16S rDNA in domestic cats from Brazil. Vet Clin Pathol 2009; 38(4): 443-452. http://dx.doi.org/10.1111/j.1939165X.2009.00158.x

Shaw SE, Birtles RJ, Day MJ. Review: Arthropod-transmitted infectious diseases of cats. J Feline Med Surg 2001; 3(4): 193-209. http://dx.doi. org/10.1053/jfms.2001.0149

Souza AM, Almeida DNP, Guterres A, Gomes R, Favacho ARM, Moreira NS, et al. Bartonelose: análise molecular e sorológica em gatos do Rio de Janeiro - Brasil. Rev Bras Cie Vet 2010; 17(1): 7-11.

Staggemeier R, Venker CA, Klein DH, Petry M, Spilki FR, Cantarelli VV. Prevalence of Bartonella henselae and Bartonella clarridgeiae in cats in the south of Brazil: a molecular study. Mem Inst Oswaldo Cruz 2010; 105(7): 873-878. http://dx.doi.org/10.1590/S007402762010000700006

Tasker S. Haemotropic mycoplasmas: what's their real significance in cats? J Feline Med Surg 2010; 12(5): 369-381. http://dx.doi.org/10.1016/j. jfms.2010.03.011

Willi B, Boretti FS, Tasker S, Meli ML, Wengi N, Reusch CE, et al. From Haemobartonella to hemoplasma: molecular methods provide new insights. Vet Microbiol 2007; 125(3-4): 197-209. http://dx.doi. org/10.1016/j.vetmic.2007.06.027

Winoto IL, Goethert H, Ibrahim IN, Yuniherlina I, Stoops C, Susanti I, et al. Bartonella species in rodents and shrews in the greater Jakarta area. Southeast Asian J Trop Med Public Health 2005; 36(6): 1523-1529.

Woods JE, Brewer MM, Hawley JR, Wisnewski N, Lappin MR. Evaluation of experimental transmission of 'Candidatus Mycoplasma haemominutum' and Mycoplasma haemofelis by Ctenocephalides felis to cats. Am J Vet Res 2005; 66(6): 1008-1012. http://dx.doi.org/10.2460/ ajvr.2005.66.1008

Ueno H, Hohdatsu T, Muramatsu Y, Koyama H, Morita C. Does coinfection of Bartonella henselae and FIV induce clinical disorders in cats? Microbiol Immunol 1996; 40(9): 617-620. 